\title{
Patterns in Special District Creation and Dissolution*
}

\author{
Christopher B. Goodman ${ }^{\dagger} \quad$ Northern Illinois University
}

Special districts are a numerous and unique form of local government in the United States. Unlike cities, counties, and towns, special districts are created and dissolved often. Using tools from the industrial organizations literature, this analysis examines patterns in creation and dissolution of special districts using Census of Governments data from 1972 to 2017. Overall, the rate of entry (creation) has been declining over time while the rate of exit (dissolution) has remained steady. New districts tend to be small relative to existing districts and and exhibit slow growth over time. Lastly, special districts do not appear susceptible to the "liability of newness" or exhibit high levels of infant organizational mortality that is common in the private sector.

Keywords: Local government, special districts, creation, dissolution

\section{Introduction}

Special districts are a numerous and unique form of local government in the United States. They provide many public services ranging in scale from the hyper-local level to multi-county, metropolitan wide services. Even with this spatial heterogeneity, special districts are providing services similar to cities or counties. Concurrently, special districts have aspects unlike other local governments. Unlike cities, they overlap each other and other governments. They also tend to be less durable than cities; both entering and exiting the local governance landscape far more often than their multi-service counterparts. In this way, special districts act more like private firms, responding to citizen and "market" demands for public services. There is a small literature on the factors associated with special district formation ${ }^{1}$ and virtually no research on dissolution. ${ }^{2}$ Even with this small literature, we know relatively little about how the special district environment has changed over time.

This research seeks to answer the question of how the pattern of special district entry and exit has changed over time. Generally, governments are presumed to be durable; having a near infinite lifespan. As a result, the local governance literature has not developed robust measures of entry and exit beyond simple counts. This research draws upon the industrial organizations literature, a literature with a long history of sophisticated methods of measuring entry and exit, to operationalize various aspects of special district creation (entry) and dissolution (exit). In doing so, a more nuanced view of special district creation and dissolution is achieved. A number of specific questions are asked in this analysis. First, how common is special district entry and exit and how large are entering and exiting districts relative to existing districts? Second, do entering special districts start small and stay small or do entrants eventually grow to sizes similar to mature

*Preliminary Draft, Please do not cite or circulate without author's permission.

${ }^{\dagger}$ May 2, 2020

${ }^{1}$ See Goodman and Leland (2019), Goodman (2018), and Shi (2017) for recent additions to this literature.

${ }^{2}$ With exception of Bauroth (2010) and Moldogaziev, Scott, and Greer (2019). 
districts? If the latter is true, how long does this process take? Do large numbers of special districts exit early in life as is common in private organizations?

There is a small literature on the factors associated with the creation of special districts and an even smaller literature on dissolution. Much of the creation literature focuses on whether changes in the autonomy of general purpose local governments lead those governments to circumvent changes by creating special districts (MacManus 1981; Nelson 1990; McCabe 2000; Carr 2006; Berry 2009; Carr and Farmer 2011; Billings and Carroll 2012; Bauroth 2015; Shi 2017; Goodman 2018; Goodman and Leland 2019). The findings are mixed within this literature with limited consensus on whether changes in autonomy result in the creation of special districts. Similarly, the small literature on special district dissolution focuses changes in autonomy. In essence, Bauroth (2010) partially asks whether dissolution is creation in reverse. The answer is a conditional yes with other demand related factors associated with dissolution. Missing from all of these analyses is a robust examination of just how common these two concepts are and how they might have changed over time.

The analysis proceeds as follows. First, the institutional context of special districts in the United States is examined. Special attention is paid to examining the factors associated with creation and dissolution of districts. Next, an overview of available data sources for special districts is conducted and an explanation of why the Census of Governments is the most appropriate for this kind of analysis is given. A number of measures of entry and exit are presented consistent with the industrial organizations literature. Finally, patterns are examined and implications for policy and research are presented.

\section{Institutional Context}

Special districts are the most popular single form of local government in the United States. According to the 2017 Census of Governments, there were 38,542 independent special districts in the United States (U.S. Census Bureau 2019). In 1952 (the first official Census of Governments), special districts numbered 12,340. This constitutes a 212 percent increase in the number of special districts in 65 years with an annualized growth rate of 1.7 percent. Both these numbers are significantly larger than growth for general purpose local governments (counties, municipalities, town/townships) who saw a 4.64 percent increase and a 0.07 annualized growth rate over the same time period.

The definition of a special district varies depending on the defining organization. At the statelevel, statutes often define the relevant aspects of special districts. For instance, a special district is defined in California state law as "any agency of the state for the local performance of governmental or proprietary functions within limited boundaries" (California Senate Local Government Committee 2010). California special districts have four distinguishing characteristics: they are a form of government, have governing boards, provide public services and/or facilities, and have defined boundaries. Even inside of this definition, there are multiple types of special districts. A district may be single or multifunction, may provide business-like services or not, or may be independent entities or dependent upon a sponsoring local government. While some of these aspects may be shared with other states, most states have their own specific definition of what constitutes a "special district."

The U.S. Census Bureau imposes a definition of a special district on local entities that is somewhat disconnected from state-level definitions. The U.S. Census Bureau defines a special district 
as governments that "are independent, special purpose governmental units that exist as separate entities with substantial administrative and fiscal independence from general purpose local governments" (U.S. Census Bureau 2019). The defining characteristics in this definition are administrative and fiscal independence. Fiscal independence is achieved through the power to determine a budget, levy taxes, charge user fees, or issue debt without review for another governmental entity. Administrative independence is achieved through fiscal independence plus having (1) an independently elected governing body, (2) a governing body representing two or more state or local governments, or (3) an appointed board with functions different from the appointing government. This definition excludes entities when fiscal or administrative independence is violated. If this definition is violated, the Census Bureau defines these districts as "dependent" and its employment and financial information is added to the sponsoring government's data. In comparing California's definition to the Census definition, the issue of independence (or not) is a key difference.

An important, universal characteristic of special districts is their territorial flexibility (Bollens 1957). Unlike cities and some towns, special districts may take on nearly any shape and may overlap other forms of local governments including other special districts. This flexibility allows special districts to take on a near infinite number of spatial arrangements. In practice, this means that the collection of local governments serving can particular area can change rapidly over short distances. There are a number of unique aspects of special districts that are largely common across states. Special districts are often free from many of the legal restricts imposed on general purpose local governments. ${ }^{3}$ Special districts can often be created without regard to assessed value, population, or territorial size (Bollens 1957). U.S. Supreme Court decisions from the 1970s and early 1980s exempt special districts from the "one person/one vote" requirement imposed on other forms of local government (Briffault 1993; Burns 1994). Votes may be apportioned in a variety of ways with property ownership being among the most popular.

\section{Why are Special Districts Created and Destroyed?}

As is typical in the local government literature, much begins with the public choice perspective of Tiebout (1956). Local governments are created to access the services they provide. Less understood in the literature is how the process dissolution should be conceptualized. Is dissolution just creation in reverse (Oakerson and Parks 1989)? If so, then the same factors associated with creation should be important. If not, one needs a different theory of special district dissolution.

Burns (1994) proposes a political economy approach to the creation of special districts. She argues that while general purpose local governments are largely created to access their powers to exclude (through local zoning ordinances), special districts are most often created to access their service delivery powers. Foster (1997) explains that three groups are involved in the process of creating a district and all must accept the benefits of a district over and above the costs. Additionally, the costs and benefits vary by group. For local residents who are the consumers of public goods and services provided, the associated benefits of specialized governments (functional specialization and territorial flexibility) outweigh the potential loss of "political visibility, accountability, and responsiveness" (Foster 1997, 101). For local government officials, the benefits associated with the distinctive nature of special districts must outweigh the loss of control and coordinating costs. Finally, private developers almost always prefer special districts as they are

\footnotetext{
${ }^{3}$ Though special districts are not entirely exempt from these restrictions. See Leigland (1992) for a more comprehensive explanation.
} 
susceptible to "capture" (Stigler 1971); however, developers will prefer general purpose local governments when such governments are friendly to development or when broad land use controls afforded to general purpose local governments are essential for generating economic rents.

A line of literature related to Burns (1994) suggests that special districts are created to circumvent restrictions imposed on general purpose local governments. Because special districts are often outside of the restrictions imposed on general purpose local governments, it can be an efficient way to continue to provide public services in the face of limited resources and/or autonomy. The literature on this potential means of creation is mixed. Dealing specifically with the imposition of tax and expenditure limits (TELs) on city and/or counties, all forms of relationship can be found with the creation of special districts. McCabe (2000) finds a positive relationship between TELs and special district creation at the state level. Nelson (1990) finds a positive relationship between the same factors at the metropolitan level. Bowler and Donovan (2004), Carr (2006), Carr and Farmer (2011), and Goodman and Leland (2019) all find a positive relationship between TELs and special districts contingent on some other influence. Even with these positive correlations, there are numerous negative (Bauroth 2015; Foster 1997) and null findings (Berry 2009; Billings and Carroll 2012; Lewis 2000; Shi 2017; Goodman 2018) in the literature.

Dissolution is far less examined. Bauroth (2010) examines whether district dissolution is simply district creation in reverse. In examining the statutes associated with special district dissolution, the conclusion is generally no. However, the empirical analysis concludes that many of the factors associated with special district creation are also associated with dissolution. While not specifically about special districts, the organizational ecology literature offers some insights (Hannan and Freeman 1977). This literature offers three potential influences on dissolution: the liability of newness, the liability of size, and density dependence. Scholars in both the organizational ecology and industrial organizations literature have observed that new organizations are more likely to close than more established ones (Hager, Galaskiewicz, and Larson 2004; Caves 1998). This is not a function of age per se, but the factors associated with youth. Stinchcombe (1965) explains there are four primary issues: the management issues associated with standing up a new organizations (creating roles, procedures, culture), the inefficiency in creating roles, issues in establishing relationships with strangers, and the uncertainty associated with establishing relationships with clients (users). Small organizations are more likely to shutter than large ones (Wholey, Christianson, and Sanchez 1992). This likely occurs because large organizations can better attract employees, have lower production costs, and can diversify both risks and revenues. Lastly, density dependency is associated with organizational demise. As Hager, Galaskiewicz, and Larson (2004) argue, this is a two factor issue. Organizations may be ill equipped to compete in a crowded market leading to organizational failure. However, organizations in niche markets may also fail due to limited legitimacy of the niche. This suggests a curvilinear relationship between density dependency and organizational mortality. Moldogaziev, Scott, and Greer (2019) examine many of the factors in relation to Texas water districts. They find support for liability of newness for special districts; younger districts are more likely to dissolve. Similarly, they find support for liability of smallness; small districts can find gathering resources and/or customers difficult and ultimately fail. Last, density dependence or external factors are not found to be influential on district mortality among Texas water district. These findings suggest applicability of the organizational ecology literature to special districts. 


\section{Measuring Special District Creation \& Dissolution with Census of Governments Data}

Special district data are notorious difficult to come by. In many states, special districts are not subjected to the same basic financial reporting regimes that many cities, towns/townships, school districts, and counties are. Consequently, even basic information about the operations of special districts are often unknown on any systematic basis. This makes conducting research on these organizations exceedingly difficult at times.

In addition to reporting issues, there is a general understanding that the formal Census Bureau definition of a "special district" is somewhat lacking or fails to fully encompass the totality of special district activity. While certainly not the first to have this debate, Leigland (1990b), Sacks (1990), and Leigland (1990a) provide a good overview of how the Census of Government's definition of a special district may or may not be lacking in completeness. The main thrust of Leigland's argument is that the rigid definition of Census, requiring both administrative and fiscal independence, excludes those special districts that are "dependent" on one or more local governments for their political leadership and/or budget authority. ${ }^{4}$ Sacks counters that some data, even somewhat flawed data, is better than nothing and Census imposes such restrictions to ensure consistency over time. The debate will likely never be fully satisfied; however, this debate highlights a fundamental feature of national-level special district research: the data are flawed yet the Census of Governments is the best, most consistent, and high quality data we have.

Similar to attempting to measure firm entry and exit, there are some fundamental issues in constructing measures of special district entry and exit. Primary among these issues are equating the number of special districts entering or exiting with the importance of such governments entering or exiting. This is an issue explained most completely in Foster (1997). She notes that simply relying on the the raw count of special districts is likely to give an inaccurate view of special districts because of the way in which the Census of Governments has historically collected data and how some special districts are used. Partially references in the debate over independent $\mathrm{v}$. dependent special districts above, the counts of special districts in the Census of Governments are subject to both undercount and overcount. Dependent special districts are a specific example of undercount, but it may also include instances where Census fails to count new special districts. Census staff endeavor to minimize this issue; however, with the volume of entering and exiting special districts and limited resources, some error is inevitable. Overcount occurs when a special district is counted when it is actually defunct. Census routinely eliminates shuttered special district (hence, our ability to observe exit); however, some special districts are never formally eliminated and linger with no staff or expenditures. Both of these issues introduce some error into the calculation of entry and exit statistics for special districts. Focusing some energy on special district spending is an effort to minimize the effects of overcount as special districts with zero expenditures will no show up in those data. Undercount is unfortunately a feature of the data that cannot be effectively minimized. ${ }^{5}$

While likely the most popular, the Census of Government is by no means the only dataset used in special district research. Much of the earliest research on special districts featured one-off, bou-

\footnotetext{
${ }^{4}$ For example, the California Institute for Local Government explains there are roughly 3,300 special districts in California in 2015. Approximately, 2/3rds are "independent" and would likely meet the Census definition of a special district; however, 1/3rd are "dependent" and would not be captured by the Census of Government's data collection. CA-ILG.

${ }^{5}$ See Goodman (2018) for a more robust conversation about what can and cannot be done about undercount in the Census of Governments.
} 
tique data hand collected by the authors with potentially dubious completeness (Kettleborough 1914, 1915; Guild 1918, 1920; Porter 1933). ${ }^{6}$ Special districts were a new phenomenon and these works pre-date much of the state-level and Census Bureau initiated data collection on special districts. More contemporaneously, California has been a site for special district research; largely attributed to the robust state-level data collection dating from at least the 1970s (Mehay 1984; Lewis 2000). Similarly, Texas has been a site of more specific special district research among scholar concerned with environmental affairs and water quality (Perrenod 1984; Moldogaziev, Scott, and Greer 2019). Leigland (1990b, 1994) used data on dependent special districts from Moody's Municipal and Government Manual to backfill Census of Governments data on independent districts. It is clear there are a number of other data sources for information on special districts.

While there are a number of other potential data sources, this analysis uses the Census of Governments. This is done for a number of reasons. First, while somewhat flawed, the data are comprehensive to all 50 states. Some states are larger users of special districts than others, but no states are immune to their impact. Therefore, a comprehensive look is necessary. Second, the Census Bureau is transparent about their definition of a "special district" and this allows tracking of definitional-led changes in the number of special districts (See U.S. Census Bureau (2019) for the latest iteration of this report). For instance, entire categories of special districts in a state may be reclassified as dependent in one Census of Governments only to be restored to independent status in the next. ${ }^{7}$ The publishing of this information allows for harmonization over time. Finally and related to the second, the Census of Governments has a consistent definition of a special district over time that allows cross-census comparisons in an apples-to-apples manner. This would be unlikely if one was to use multiple state-level datasets to examine special district entry and exit.

\section{Data Construction}

As explained in the previous section, the largest and most comprehensive database of information on special districts in the United States is the Census of Governments. Conducted every 5 years on years ending in " 2 " and " 7 " by the U.S. Census Bureau, the Census of Governments provides data on all local governments in the United States in three areas delineated by the part of the survey: organizations, finance, and employment. The analysis to follow takes information from the first two parts to construct measures of special district entry and exit.

The Census Bureau maintains a comprehensive database of local governments in the United States. Called the Governments Integrated Directory (GID), it is a continuously updated database that can be used to track special districts over time. In the GID, each government is identified with a 14 digit government unit code that can be disaggregated to provide all the pertinent information to track special districts across time and aggregate those districts to geographic levels that are meaningful (U.S. Census Bureau 2006). Specifically, the government unit code allows the tracking of individual special districts over time. This allows a researcher to identify when a new special district is added to the directory and when districts are removed. Additionally, the government unit code identifies the state and county of the district allowing for entry and exit measures to be aggregated up to the state and metropolitan levels.

\footnotetext{
${ }^{6}$ This is by no means the fault of the authors in this time period.

${ }^{7}$ This occurred in Oklahoma where the Census Bureau classified certain community trust special districts as independent for a number of years only to reclassify them as dependent in a particular year, and then reclassified them again as independent in the subsequent Census.
} 
A special district is registered as "created" the first year it appears in the GID. In actuality, a special district may be created at any point between two Census of Governments, but it is registered at the end of the period. A special district is registered as "dissolved" if it fails to show up in the Census of Governments data for more than one consecutive round of data collection. The Census Bureau make a significant effort to clean the CoG data and eliminate non-response. This allows for a cleaner estimation of exit.

\section{Creation \& Dissolution Measures}

This analysis relies heavily on the prior work of Dunne, Roberts, and Samuelson (1988) to operationalize special district entry and exit. Dunne, Roberts, and Samuelson (1988) develop a series of measures of manufacturing firm entry and exit using data from the Census of Manufacturers (CoM) conducted between 1963 and 1982. The structure of the CoM is similar to that of the CoG in that it is a census of organizations conducted every five years. This every-five-year structure presents unique challenges in measuring entry and exit as they may occur at any time, but are only observed on a five year schedule. Building on Dunne, Roberts, and Samuelson (1988), the following components are specified.

$$
\begin{aligned}
& N E_{i t}=\text { number of special districts created in state/CBSA } i \text { between census years } \\
& t-1 \text { and } t \\
& N T_{i t}=\text { total number of special districts in state/CBSA } i \text { between census years } \\
& N X_{i t-1}=\begin{array}{l}
\text { number of special districts dissolved in state/CBSA } i \text { between census } \\
\text { years } t-1 \text { and } t
\end{array} \\
& Q E_{i t}=\text { total expenditures of created special districts in state/CBSA } i \text { between } \\
& \begin{array}{l}
\text { census years } t-1 \text { and } t \\
Q T_{i t}=
\end{array} \\
& Q T_{i t} \quad=\text { years } t-1 \text { and } t \\
& Q X_{i t-1}=\begin{array}{l}
\text { total expenditures of dissolved special districts in state/CBSA } i \text { between } \\
\text { census years } t-1 \text { and } t
\end{array}
\end{aligned}
$$

These components are used to construct the final measures of entry and exit. They are based on two primary concepts: the number of special districts (created, dissolved, and total) and the expenditures of special districts (created, dissolved, and total).

Using the variables outlined above, both the entry (1) and exit (2) rate are specified.

$$
\begin{gathered}
E R_{i t}=\frac{N E_{i t}}{N T_{i t-1}} \\
X R_{i t-1}=\frac{N X_{i t-1}}{N T_{i t-1}}
\end{gathered}
$$

The exit rate is specified with the total number of special districts in the previous period. This represents the total pool of districts that could potentially exit in the following period. There is no equivalent pool for potential entrants. To maintain consistency with Dunne, Roberts, and Samuelson (1988), the previous period total is used. Both of these measures allow for the examination of the proportion of entrants and exiters as a function of the total number of special districts in the previous period.

In the private sector, entering and exiting firms tend to be smaller than existing firms (Dunne, Roberts, and Samuelson 1988; Caves 1998); however, in the public sector, this is an open question. 
If special districts are indeed used to access the services they provide as Burns (1994) contends, then entering districts may be just as large as incumbent districts. In a similar fashion, if exiting districts are wound down, then we might expect exiting districts to be small. However, if exiting districts transfer their service responsibilities to other governments and then exit, we might expect exiting districts to be of similar size to existing districts. Entrants market share (3) and exiter market share (4) demonstrate the market share of entrants in their first observed year and the market share of exiters in their last observed year of life.

$$
\begin{gathered}
E S H_{i t}=\frac{Q E_{i t}}{Q T_{i t}} \\
X S H_{i t-1}=\frac{Q X_{i t-1}}{Q T_{i t-1}}
\end{gathered}
$$

The last set of measures examine the average size of entering districts relative to existing districts (5) and the average size of exiting districts relative to existing districts (6). Both of these measures allow for a further examination of the points above.

$$
\begin{gathered}
E R S_{i t}=\frac{Q E_{i t} / Q T_{i t}}{\left(Q T_{i t}-Q E_{i t}\right) /\left(N T_{i t}-N E_{i t}\right)} \\
X S H_{i t-1}=\frac{Q X_{i t} / N T_{i t-1}}{\left(Q T_{i t-1}-Q X_{i t-1}\right) /\left(N T_{i t-1}-N X_{i t-1}\right)}
\end{gathered}
$$

In both instances, the denominator excludes entering $\left(E R S_{i t}\right)$ and exiting $\left(X S H_{i t-1}\right)$ districts.

\section{Average Creation \& Dissolution Statistics}

The description of entry and exit patterns begins with an examination of the median level of entry and exit of special districts across states and core based statistical areas (CBSA). Table 1 reports six measures of entry and exit between each pair of census years. As mentioned previously, two groupings of entry and exit variables are presented: one aggregated to the state level and another aggregated to the core based statistical area level.

There are a number of observations of note in table 1 . The median entry rate among states varies from 0.012 to 0.184 across census years. On average, 10.1 percent of special districts in each state in each census year were not in operation the in the previous census. Among CBSAs, the median entry rate varies from 0.000 to 0.167 with an average of 9 percent of special districts in each CBSA in each census year were not in operation in the previous census year. This can be seen graphically in figure 1. The trend for both states and CBSAs is lower entry rates over time. For both states and CBSAs, the median entrant market share is low ranging between 0.001 to 0.152 for states and 0.000 to 0.052 for CBSAs. On average, new special districts are responsible for 5.7 percent of special districts spending at the state level and 1.8 of spending at the CBSA level. In comparing entry rates and entrant market share, new special districts tend to be smaller than existing districts. On average, new special districts in a state in a census year were 44.3 percent the size of existing special districts. For CBSAs, the percentage is lower with new special districts being 11.1 percent the size of existing special districts.

The exit variables in table 1 demonstrate a somewhat similar trend to the entry variables. Exit rates are higher in among state aggregates than CBSAs. However, exit rates are generally smaller than entry rates. As can be seen in figure 2, the exit rate at both the state- and CBSA-level is 


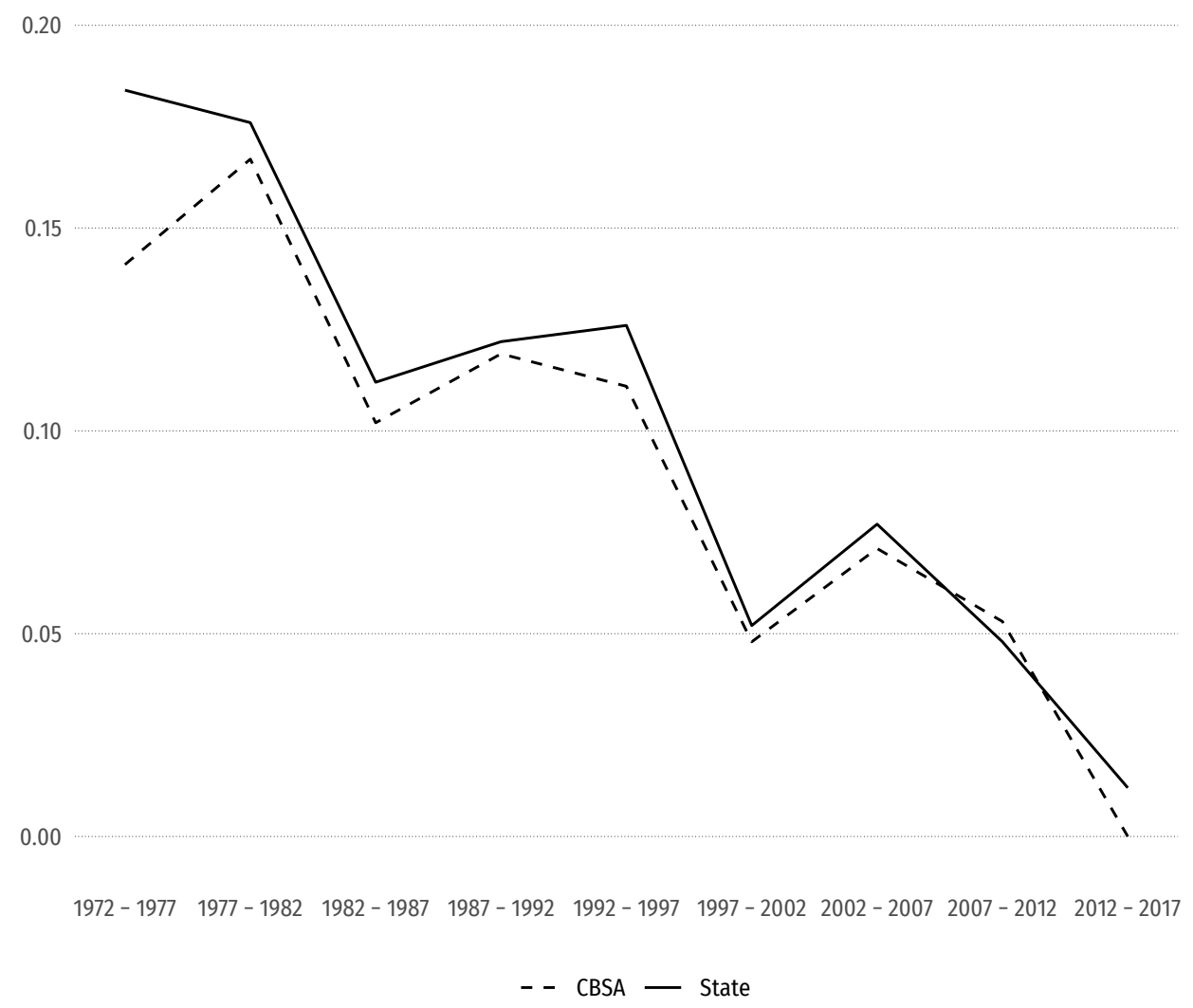

Figure 1: Median Special District Entry Rate (ER) 
Table 1: Entry and Exit Variables for Special Districts

(Medians Over 48 States and 378 Core Based Statistical Areas)

\begin{tabular}{lccccccccc}
\hline & $1972-$ & $1977-$ & $1982-$ & $1987-$ & $1992-$ & $1997-$ & $2002-$ & $2007-$ & $2012-$ \\
& 1977 & 1982 & 1987 & 1992 & 1997 & 2002 & 2007 & 2012 & 2017 \\
\hline Entry rate $(E R)$ & & & & & & & & & \\
$\quad$ State & 0.184 & 0.176 & 0.112 & 0.122 & 0.126 & 0.052 & 0.077 & 0.048 & 0.012 \\
$\quad$ CBSA & 0.141 & 0.167 & 0.102 & 0.119 & 0.111 & 0.048 & 0.071 & 0.053 & 0.000 \\
Entrant market share $(E S H)$ & & & & & & & & \\
$\quad$ State & 0.085 & 0.152 & 0.048 & 0.059 & 0.059 & 0.037 & 0.055 & 0.019 & 0.001 \\
$\quad$ CBSA & 0.018 & 0.052 & 0.011 & 0.017 & 0.033 & 0.005 & 0.022 & 0.005 & 0.000 \\
Entrant relative size & $(E R S)$ & & & & & & & & \\
$\quad$ State & 0.593 & 0.734 & 0.430 & 0.423 & 0.483 & 0.391 & 0.544 & 0.347 & 0.038 \\
$\quad$ CBSA & 0.067 & 0.293 & 0.063 & 0.091 & 0.192 & 0.049 & 0.184 & 0.061 & 0.000 \\
Exit rate $(X R)$ & & & & & & & & & \\
$\quad$ State & 0.064 & 0.082 & 0.057 & 0.057 & 0.045 & 0.053 & 0.071 & 0.043 & \\
$\quad$ CBSA & 0.040 & 0.074 & 0.046 & 0.050 & 0.050 & 0.046 & 0.067 & 0.039 & \\
Exiter market share & $(X S H)$ & & & & & & & & \\
$\quad$ State & 0.002 & 0.002 & 0.003 & 0.010 & 0.007 & 0.010 & 0.019 & 0.007 & \\
$\quad$ CBSA & 0.000 & 0.000 & 0.000 & 0.000 & 0.000 & 0.000 & 0.002 & 0.001 & \\
Exiter relative size $(X R S)$ & & & & & & & & \\
$\quad$ State & 0.021 & 0.047 & 0.049 & 0.142 & 0.114 & 0.139 & 0.381 & 0.272 & \\
$\quad$ CBSA & 0.000 & 0.000 & 0.000 & 0.000 & 0.000 & 0.006 & 0.021 & 0.022 & \\
\hline
\end{tabular}

relatively stable over time, generally hover between five and ten percent. The market share of exiting special districts is also low suggesting that districts are wound down before they exit. This tells the story of a relative minority of districts exiting in any given census year and their impact on the the special district "market" is relatively muted.

Taken together, entry and exit appears to be fairly common among special districts relative to the general assumption of organizational durability; however, the entry rate has been declining over time and the exit rate is somewhat stable leading to lower levels of overall (net) growth. Entering special districts tend to be small, relative to existing districts, suggesting these districts are created to provide new (or supplement existing) public services. If services were directly transferred to special districts, we should expect to see much larger entering districts. Exiting special districts also tend to be small suggesting that such districts are intentionally wound down before they are shuttered permanently.

\section{Longitudinal Aspects of Creation \& Dissolution}

In this section I turn my attention away from the cross-sectional aspects of special district entry and exit and focus on the longitudinal factors. In doing so a number of questions can be answered. Do entering special districts start small and stay small or do entrants eventually grow to sizes similar to mature districts? If the latter is true, how long does this process take? Do large numbers of special districts exit early in life as is common in private organizations? These questions require tracking cohorts of districts across time.

Table 2 presents market shares for special districts for each entry cohort in each census year. The table presents medians across 48 states and 378 CBSAs in each time period with the interquar- 


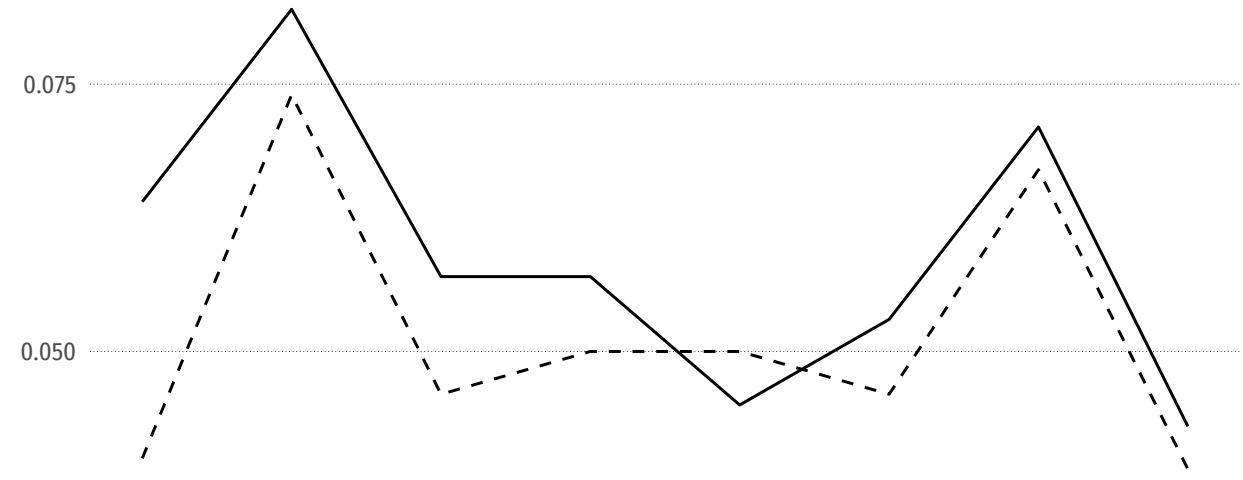

0.025

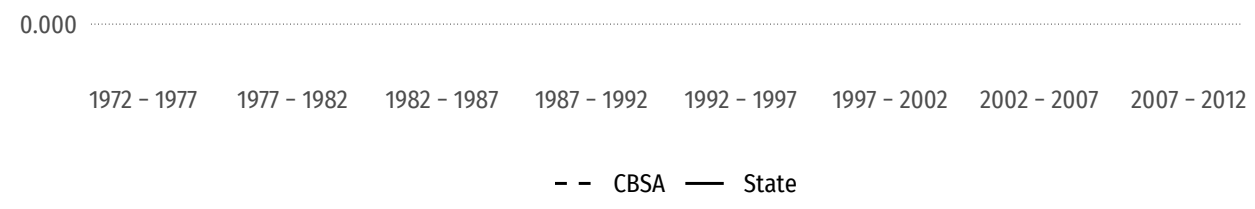

Figure 2: Median Special District Exit Rate (XR) 
tile range in parentheses. In general, market share declines in census years following entry. Averaged across all time periods, the market share of entering special districts is 5.7 percent among states and 1.8 percent among CBSAs. In the following two census years, the average market share for entering cohorts declines slight to 5.6 and 5.4 percent for states and 1.8 percent and 1.6 percent for CBSAs. With two exceptions (the 1992 entry cohort for both states and CBSAs and the 1977 CBSA cohort), the largest cohort-specific market share is in the first year.

As Dunne, Roberts, and Samuelson (1988) note, the decline in market share of entering special districts over time can likely be attributed to two factors: the change in the size of surviving members of the cohort or the exit of special districts from the cohort. To investigate the first of these potential factors, table 3 shows the average size of surviving districts relative to all districts by cohort. In general, entering cohorts grow from their initial size as the cohort ages; however, special districts in entering cohorts are typically small relative to existing districts. For nearly all entering cohorts across census years, none achieve a size comparable to existing districts on average. Earlier cohorts (1977 and 1982 in particular) appear to be more successful in growing to a size similar to existing districts, but many more recent cohorts fail to achieve a size even 50 percent of existing districts.

Exploring the other factor of declining market share over time, table 4 shows the cumulative exit rate by entry cohort. Overall, exit rate is low among cohorts and are significantly lower for metropolitan areas than for states in the early years after creation. One standout trend is existing districts in 1972 have a much larger cumulative exit rate than the cohorts that follow suggesting that longevity may be a factor in exit (i.e. obsolesce). Comparing states to CBSAs, the lower rate of exit among CBSAs suggests a higher level of durability for metropolitan special districts than the broader collection of special districts in states.

In summary, the market share of each entering cohort of special districts tends to decline over time. Rather than being the result of high exit rates that are common in the private sector, it appears this is the result of lackluster growth in expenditures relative to existing special districts. As new cohorts of districts are created, this further dilutes the relative size of existing districts. This paints a picture of more recent cohorts (post-1972) being small, not particularly fast growing in expenditures, and exiting at a low rate. While there are difference between state- and CBSAlevel variables, the difference are minor.

\section{Policy Implications \& Conclusions}

Special districts are an important part of the local governance system. However, unlike general purpose local governments, special districts have aspects of public organizations and aspects of private organizations. Principle among these, special districts enter and exit the public "market" often. While there is a robust literature on special district entry and a more limited literature on exit $^{8}$ there is limited work on how one should measure these concepts. Typical among the literature are raw counts of entry and exit that can be somewhat misleading. This analysis takes a different approach by drawing upon entry and exit variables typical in the industrial organizations literature. In doing so, a number of interesting and largely unexplored questions can be answered. First, how common is special district entry and exit and how large are entering and exiting districts? Second, do entering special districts start small and stay small or do entrants eventually

\footnotetext{
${ }^{8}$ The analyses in this literature are typically not conceptualized in these terms.
} 
Table 2: Market Share $(E R H)$ of New Special Districts by Cohort

\begin{tabular}{|c|c|c|c|c|c|c|c|c|c|c|}
\hline & 1972 & 1977 & 1982 & 1987 & 1992 & 1997 & 2002 & 2007 & 2012 & 2017 \\
\hline \multicolumn{11}{|l|}{ States } \\
\hline 1972 Districts & 1.000 & $\begin{array}{c}0.915 \\
(0.218)\end{array}$ & $\begin{array}{c}0.712 \\
(0.270)\end{array}$ & $\begin{array}{c}0.585 \\
(0.233)\end{array}$ & $\begin{array}{c}0.596 \\
(0.280)\end{array}$ & $\begin{array}{c}0.519 \\
(0.311)\end{array}$ & $\begin{array}{c}0.517 \\
(0.343)\end{array}$ & $\begin{array}{c}0.444 \\
(0.374)\end{array}$ & $\begin{array}{c}0.474 \\
(0.370)\end{array}$ & $\begin{array}{c}0.444 \\
(0.369)\end{array}$ \\
\hline 1977 Entry Cohort & - & $\begin{array}{c}0.085 \\
(0.218)\end{array}$ & $\begin{array}{c}0.075 \\
(0.128)\end{array}$ & $\begin{array}{c}0.070 \\
(0.164)\end{array}$ & $\begin{array}{c}0.057 \\
(0.140)\end{array}$ & $\begin{array}{c}0.068 \\
(0.111)\end{array}$ & $\begin{array}{c}0.051 \\
(0.109)\end{array}$ & $\begin{array}{c}0.063 \\
(0.107)\end{array}$ & $\begin{array}{c}0.051 \\
(0.094)\end{array}$ & $\begin{array}{c}0.053 \\
(0.101)\end{array}$ \\
\hline 1982 Entry Cohort & - & - & $\begin{array}{c}0.152 \\
(0.249)\end{array}$ & $\begin{array}{c}0.137 \\
(0.228)\end{array}$ & $\begin{array}{c}0.104 \\
(0.209)\end{array}$ & $\begin{array}{c}0.087 \\
(0.141)\end{array}$ & $\begin{array}{c}0.081 \\
(0.117)\end{array}$ & $\begin{array}{c}0.070 \\
(0.112)\end{array}$ & $\begin{array}{c}0.079 \\
(0.097)\end{array}$ & $\begin{array}{c}0.059 \\
(0.121)\end{array}$ \\
\hline 1987 Entry Cohort & - & - & - & $\begin{array}{c}0.048 \\
(0.108)\end{array}$ & $\begin{array}{c}0.037 \\
(0.080)\end{array}$ & $\begin{array}{c}0.054 \\
(0.097)\end{array}$ & $\begin{array}{c}0.041 \\
(0.085)\end{array}$ & $\begin{array}{c}0.034 \\
(0.067)\end{array}$ & $\begin{array}{c}0.035 \\
(0.055)\end{array}$ & $\begin{array}{c}0.035 \\
(0.069)\end{array}$ \\
\hline 1992 Entry Cohort & - & - & - & - & $\begin{array}{c}0.059 \\
(0.092)\end{array}$ & $\begin{array}{c}0.071 \\
(0.097)\end{array}$ & $\begin{array}{c}0.050 \\
(0.094)\end{array}$ & $\begin{array}{c}0.055 \\
(0.089)\end{array}$ & $\begin{array}{c}0.048 \\
(0.054)\end{array}$ & $\begin{array}{c}0.047 \\
(0.053)\end{array}$ \\
\hline 1997 Entry Cohort & - & - & - & - & - & $\begin{array}{c}0.059 \\
(0.106)\end{array}$ & $\begin{array}{c}0.047 \\
(0.068)\end{array}$ & $\begin{array}{c}0.045 \\
(0.047)\end{array}$ & $\begin{array}{c}0.046 \\
(0.050)\end{array}$ & $\begin{array}{c}0.036 \\
(0.056)\end{array}$ \\
\hline 2002 Entry Cohort & - & - & - & - & - & - & $\begin{array}{c}0.037 \\
(0.059)\end{array}$ & $\begin{array}{c}0.023 \\
(0.038)\end{array}$ & $\begin{array}{c}0.022 \\
(0.033)\end{array}$ & $\begin{array}{c}0.014 \\
(0.052)\end{array}$ \\
\hline 2007 Entry Cohort & - & - & - & - & - & - & - & $\begin{array}{c}0.055 \\
(0.073)\end{array}$ & $\begin{array}{c}0.038 \\
(0.068)\end{array}$ & $\begin{array}{c}0.036 \\
(0.082)\end{array}$ \\
\hline 2012 Entry Cohort & - & - & - & - & - & - & - & - & $\begin{array}{c}0.019 \\
(0.036)\end{array}$ & $\begin{array}{c}0.022 \\
(0.036)\end{array}$ \\
\hline 2017 Entry Cohort & - & - & - & - & - & - & - & - & - & $\begin{array}{c}0.001 \\
(0.004)\end{array}$ \\
\hline \multicolumn{11}{|l|}{ CBSAs } \\
\hline 1972 Districts & 1.000 & $\begin{array}{c}0.982 \\
(0.192)\end{array}$ & $\begin{array}{c}0.789 \\
(0.533)\end{array}$ & $\begin{array}{c}0.690 \\
(0.499)\end{array}$ & $\begin{array}{c}0.599 \\
(0.568)\end{array}$ & $\begin{array}{c}0.502 \\
(0.564)\end{array}$ & $\begin{array}{c}0.470 \\
(0.530)\end{array}$ & $\begin{array}{c}0.436 \\
(0.528)\end{array}$ & $\begin{array}{c}0.419 \\
(0.529)\end{array}$ & $\begin{array}{c}0.364 \\
(0.558)\end{array}$ \\
\hline 1977 Entry Cohort & - & $\begin{array}{c}0.018 \\
(0.192)\end{array}$ & $\begin{array}{c}0.022 \\
(0.158)\end{array}$ & $\begin{array}{c}0.021 \\
(0.126)\end{array}$ & $\begin{array}{c}0.013 \\
(0.100)\end{array}$ & $\begin{array}{c}0.011 \\
(0.093)\end{array}$ & $\begin{array}{c}0.013 \\
(0.085)\end{array}$ & $\begin{array}{c}0.010 \\
(0.073)\end{array}$ & $\begin{array}{c}0.008 \\
(0.066)\end{array}$ & $\begin{array}{c}0.006 \\
(0.064)\end{array}$ \\
\hline 1982 Entry Cohort & - & - & $\begin{array}{c}0.052 \\
(0.258)\end{array}$ & $\begin{array}{c}0.042 \\
(0.234)\end{array}$ & $\begin{array}{c}0.033 \\
(0.178)\end{array}$ & $\begin{array}{c}0.027 \\
(0.133)\end{array}$ & $\begin{array}{c}0.023 \\
(0.132)\end{array}$ & $\begin{array}{c}0.021 \\
(0.124)\end{array}$ & $\begin{array}{c}0.020 \\
(0.113)\end{array}$ & $\begin{array}{c}0.013 \\
(0.097)\end{array}$ \\
\hline 1987 Entry Cohort & - & - & - & $\begin{array}{c}0.011 \\
(0.096)\end{array}$ & $\begin{array}{c}0.010 \\
(0.082)\end{array}$ & $\begin{array}{c}0.012 \\
(0.066)\end{array}$ & $\begin{array}{c}0.009 \\
(0.068)\end{array}$ & $\begin{array}{c}0.005 \\
(0.050)\end{array}$ & $\begin{array}{c}0.004 \\
(0.041)\end{array}$ & $\begin{array}{c}0.002 \\
(0.045)\end{array}$ \\
\hline 1992 Entry Cohort & - & - & - & - & $\begin{array}{c}0.015 \\
(0.106)\end{array}$ & $\begin{array}{c}0.027 \\
(0.108)\end{array}$ & $\begin{array}{c}0.023 \\
(0.103)\end{array}$ & $\begin{array}{c}0.016 \\
(0.085)\end{array}$ & $\begin{array}{c}0.011 \\
(0.062)\end{array}$ & $\begin{array}{c}0.007 \\
(0.063)\end{array}$ \\
\hline 1997 Entry Cohort & - & - & - & - & - & $\begin{array}{c}0.033 \\
(0.128)\end{array}$ & $\begin{array}{c}0.022 \\
(0.093)\end{array}$ & $\begin{array}{c}0.014 \\
(0.070)\end{array}$ & $\begin{array}{c}0.010 \\
(0.065)\end{array}$ & $\begin{array}{c}0.009 \\
(0.068)\end{array}$ \\
\hline 2002 Entry Cohort & - & - & - & - & - & - & $\begin{array}{c}0.005 \\
(0.058)\end{array}$ & $\begin{array}{c}0.002 \\
(0.042)\end{array}$ & $\begin{array}{c}0.001 \\
(0.033)\end{array}$ & $\begin{array}{c}0.001 \\
(0.024)\end{array}$ \\
\hline 2007 Entry Cohort & - & - & - & - & - & - & - & $\begin{array}{c}0.022 \\
(0.108)\end{array}$ & $\begin{array}{c}0.013 \\
(0.075)\end{array}$ & $\begin{array}{c}0.010 \\
(0.071)\end{array}$ \\
\hline 2012 Entry Cohort & - & - & - & - & - & - & - & - & $\begin{array}{c}0.005 \\
(0.039)\end{array}$ & $\begin{array}{c}0.004 \\
(0.046)\end{array}$ \\
\hline 2017 Entry Cohort & - & - & - & - & - & - & - & - & - & $\begin{array}{c}0.000 \\
(0.000)\end{array}$ \\
\hline
\end{tabular}

Notes: Medians; interquartile range in parentheses. 
Table 3: Average Size of Surviving Districts Relative to All Districts (ERS) by Cohort

\begin{tabular}{|c|c|c|c|c|c|c|c|c|c|c|}
\hline & 1972 & 1977 & 1982 & 1987 & 1992 & 1997 & 2002 & 2007 & 2012 & 2017 \\
\hline \multicolumn{11}{|l|}{ States } \\
\hline 1972 Districts & 1.000 & $\begin{array}{c}1.052 \\
(0.226)\end{array}$ & $\begin{array}{c}1.055 \\
(0.382)\end{array}$ & $\begin{array}{c}1.001 \\
(0.332)\end{array}$ & $\begin{array}{c}1.094 \\
(0.371)\end{array}$ & $\begin{array}{c}1.101 \\
(0.452)\end{array}$ & $\begin{array}{c}1.114 \\
(0.544)\end{array}$ & $\begin{array}{c}1.130 \\
(0.635)\end{array}$ & $\begin{array}{c}1.178 \\
(0.726)\end{array}$ & $\begin{array}{c}1.147 \\
(0.836)\end{array}$ \\
\hline 1977 Entry Cohort & - & $\begin{array}{c}0.620 \\
(1.193)\end{array}$ & $\begin{array}{c}0.732 \\
(0.990)\end{array}$ & $\begin{array}{c}0.657 \\
(1.342)\end{array}$ & $\begin{array}{c}0.787 \\
(1.597)\end{array}$ & $\begin{array}{c}0.931 \\
(1.516)\end{array}$ & $\begin{array}{c}0.818 \\
(1.750)\end{array}$ & $\begin{array}{c}0.845 \\
(1.586)\end{array}$ & $\begin{array}{c}0.811 \\
(1.464)\end{array}$ & $\begin{array}{c}0.818 \\
(1.607)\end{array}$ \\
\hline 1982 Entry Cohort & - & - & $\begin{array}{c}0.776 \\
(1.014)\end{array}$ & $\begin{array}{c}0.849 \\
(1.052)\end{array}$ & $\begin{array}{c}0.878 \\
(1.149)\end{array}$ & $\begin{array}{c}0.854 \\
(1.227)\end{array}$ & $\begin{array}{c}0.890 \\
(1.198)\end{array}$ & $\begin{array}{c}1.060 \\
(1.464)\end{array}$ & $\begin{array}{c}1.096 \\
(1.541)\end{array}$ & $\begin{array}{c}0.917 \\
(1.588)\end{array}$ \\
\hline 1987 Entry Cohort & - & - & - & $\begin{array}{c}0.458 \\
(0.662)\end{array}$ & $\begin{array}{c}0.471 \\
(0.787)\end{array}$ & $\begin{array}{c}0.749 \\
(1.045)\end{array}$ & $\begin{array}{c}0.588 \\
(0.886)\end{array}$ & $\begin{array}{c}0.592 \\
(0.944)\end{array}$ & $\begin{array}{c}0.593 \\
(1.076)\end{array}$ & $\begin{array}{c}0.734 \\
(1.042)\end{array}$ \\
\hline 1992 Entry Cohort & - & - & - & - & $\begin{array}{c}0.491 \\
(0.616)\end{array}$ & $\begin{array}{c}0.630 \\
(0.918)\end{array}$ & $\begin{array}{c}0.706 \\
(0.716)\end{array}$ & $\begin{array}{c}0.612 \\
(1.031)\end{array}$ & $\begin{array}{c}0.630 \\
(0.987)\end{array}$ & $\begin{array}{c}0.691 \\
(0.835)\end{array}$ \\
\hline 1997 Entry Cohort & - & - & - & - & - & $\begin{array}{c}0.531 \\
(0.520)\end{array}$ & $\begin{array}{c}0.488 \\
(0.576)\end{array}$ & $\begin{array}{c}0.464 \\
(0.609)\end{array}$ & $\begin{array}{c}0.466 \\
(0.738)\end{array}$ & $\begin{array}{c}0.399 \\
(0.712)\end{array}$ \\
\hline 2002 Entry Cohort & - & - & - & - & - & - & $\begin{array}{c}0.467 \\
(0.885)\end{array}$ & $\begin{array}{c}0.425 \\
(0.901)\end{array}$ & $\begin{array}{c}0.501 \\
(1.016)\end{array}$ & $\begin{array}{c}0.513 \\
(0.600)\end{array}$ \\
\hline 2007 Entry Cohort & - & - & - & - & - & - & - & $\begin{array}{c}0.658 \\
(0.826)\end{array}$ & $\begin{array}{c}0.688 \\
(0.993)\end{array}$ & $\begin{array}{c}0.514 \\
(0.824)\end{array}$ \\
\hline 2012 Entry Cohort & - & - & - & - & - & - & - & - & $\begin{array}{c}0.362 \\
(0.942)\end{array}$ & $\begin{array}{c}0.471 \\
(0.728)\end{array}$ \\
\hline 2017 Entry Cohort & - & - & - & - & - & - & - & - & - & $\begin{array}{c}0.054 \\
(0.425)\end{array}$ \\
\hline \multicolumn{11}{|l|}{$C B S A \mathrm{~s}$} \\
\hline 1972 Districts & 1.000 & $\begin{array}{c}1.031 \\
(0.142)\end{array}$ & $\begin{array}{c}1.009 \\
(0.513)\end{array}$ & $\begin{array}{c}1.041 \\
(0.597)\end{array}$ & $\begin{array}{c}1.053 \\
(0.779)\end{array}$ & $\begin{array}{c}1.042 \\
(0.914)\end{array}$ & $\begin{array}{c}1.059 \\
(0.947)\end{array}$ & $\begin{array}{c}1.000 \\
(0.945)\end{array}$ & $\begin{array}{c}1.000 \\
(1.030)\end{array}$ & $\begin{array}{c}1.005 \\
(1.136)\end{array}$ \\
\hline 1977 Entry Cohort & - & $\begin{array}{c}0.407 \\
(1.252)\end{array}$ & $\begin{array}{c}0.498 \\
(1.416)\end{array}$ & $\begin{array}{c}0.433 \\
(1.313)\end{array}$ & $\begin{array}{c}0.424 \\
(1.355)\end{array}$ & $\begin{array}{c}0.528 \\
(1.363)\end{array}$ & $\begin{array}{c}0.547 \\
(1.331)\end{array}$ & $\begin{array}{c}0.611 \\
(1.422)\end{array}$ & $\begin{array}{c}0.569 \\
(1.396)\end{array}$ & $\begin{array}{c}0.521 \\
(1.372)\end{array}$ \\
\hline 1982 Entry Cohort & - & - & $\begin{array}{c}0.571 \\
(1.425)\end{array}$ & $\begin{array}{c}0.546 \\
(1.399)\end{array}$ & $\begin{array}{c}0.523 \\
(1.632)\end{array}$ & $\begin{array}{c}0.538 \\
(1.397)\end{array}$ & $\begin{array}{c}0.562 \\
(1.420)\end{array}$ & $\begin{array}{c}0.608 \\
(1.485)\end{array}$ & $\begin{array}{c}0.686 \\
(1.688)\end{array}$ & $\begin{array}{c}0.493 \\
(1.832)\end{array}$ \\
\hline 1987 Entry Cohort & - & - & - & $\begin{array}{c}0.265 \\
(0.828)\end{array}$ & $\begin{array}{c}0.299 \\
(1.122)\end{array}$ & $\begin{array}{c}0.396 \\
(1.064)\end{array}$ & $\begin{array}{c}0.338 \\
(1.020)\end{array}$ & $\begin{array}{c}0.313 \\
(0.969)\end{array}$ & $\begin{array}{c}0.352 \\
(0.984)\end{array}$ & $\begin{array}{c}0.312 \\
(0.997)\end{array}$ \\
\hline 1992 Entry Cohort & - & - & - & - & $\begin{array}{c}0.215 \\
(0.743)\end{array}$ & $\begin{array}{c}0.409 \\
(1.077)\end{array}$ & $\begin{array}{c}0.423 \\
(1.050)\end{array}$ & $\begin{array}{c}0.468 \\
(1.119)\end{array}$ & $\begin{array}{c}0.409 \\
(1.071)\end{array}$ & $\begin{array}{c}0.444 \\
(1.162)\end{array}$ \\
\hline 1997 Entry Cohort & - & - & - & - & - & $\begin{array}{c}0.349 \\
(0.787)\end{array}$ & $\begin{array}{c}0.335 \\
(0.830)\end{array}$ & $\begin{array}{c}0.308 \\
(0.839)\end{array}$ & $\begin{array}{c}0.291 \\
(0.896)\end{array}$ & $\begin{array}{c}0.293 \\
(1.005)\end{array}$ \\
\hline 2002 Entry Cohort & - & - & - & - & - & - & $\begin{array}{c}0.250 \\
(0.985)\end{array}$ & $\begin{array}{c}0.222 \\
(0.844)\end{array}$ & $\begin{array}{c}0.246 \\
(0.854)\end{array}$ & $\begin{array}{c}0.202 \\
(0.900)\end{array}$ \\
\hline 2007 Entry Cohort & - & - & - & - & - & - & - & $\begin{array}{c}0.447 \\
(0.966)\end{array}$ & $\begin{array}{c}0.340 \\
(1.053)\end{array}$ & $\begin{array}{c}0.348 \\
(0.981)\end{array}$ \\
\hline 2012 Entry Cohort & - & - & - & - & - & - & - & - & $\begin{array}{c}0.192 \\
(0.645)\end{array}$ & $\begin{array}{c}0.229 \\
(0.878)\end{array}$ \\
\hline 2017 Entry Cohort & - & - & - & - & - & - & - & - & - & $\begin{array}{c}0.097 \\
(0.527)\end{array}$ \\
\hline
\end{tabular}

Notes: Medians; interquartile range in parentheses. 
Table 4: Cumulative Exit Rates (XR) of Entry Cohort

\begin{tabular}{|c|c|c|c|c|c|c|c|c|c|}
\hline & 1977 & 1982 & 1987 & 1992 & 1997 & 2002 & 2007 & 2012 & 2017 \\
\hline \multicolumn{10}{|l|}{ States } \\
\hline 1972 Districts & $\begin{array}{c}0.064 \\
(0.044)\end{array}$ & $\begin{array}{c}0.122 \\
(0.086)\end{array}$ & $\begin{array}{c}0.145 \\
(0.107)\end{array}$ & $\begin{array}{c}0.170 \\
(0.108)\end{array}$ & $\begin{array}{c}0.187 \\
(0.114)\end{array}$ & $\begin{array}{c}0.194 \\
(0.111)\end{array}$ & $\begin{array}{c}0.206 \\
(0.110)\end{array}$ & $\begin{array}{c}0.219 \\
(0.110)\end{array}$ & $\begin{array}{c}0.227 \\
(0.097)\end{array}$ \\
\hline 1977 Entry Cohort & - & $\begin{array}{c}0.025 \\
(0.020)\end{array}$ & $\begin{array}{c}0.036 \\
(0.029)\end{array}$ & $\begin{array}{c}0.041 \\
(0.037)\end{array}$ & $\begin{array}{c}0.048 \\
(0.047)\end{array}$ & $\begin{array}{c}0.054 \\
(0.052)\end{array}$ & $\begin{array}{c}0.060 \\
(0.054)\end{array}$ & $\begin{array}{c}0.064 \\
(0.054)\end{array}$ & $\begin{array}{c}0.067 \\
(0.054)\end{array}$ \\
\hline 1982 Entry Cohort & - & - & $\begin{array}{c}0.017 \\
(0.018)\end{array}$ & $\begin{array}{c}0.031 \\
(0.022)\end{array}$ & $\begin{array}{c}0.041 \\
(0.032)\end{array}$ & $\begin{array}{c}0.050 \\
(0.042)\end{array}$ & $\begin{array}{c}0.068 \\
(0.044)\end{array}$ & $\begin{array}{c}0.071 \\
(0.053)\end{array}$ & $\begin{array}{c}0.074 \\
(0.055)\end{array}$ \\
\hline 1987 Entry Cohort & - & - & - & $\begin{array}{c}0.015 \\
(0.009)\end{array}$ & $\begin{array}{c}0.020 \\
(0.020)\end{array}$ & $\begin{array}{c}0.025 \\
(0.026)\end{array}$ & $\begin{array}{c}0.032 \\
(0.024)\end{array}$ & $\begin{array}{c}0.038 \\
(0.026)\end{array}$ & $\begin{array}{c}0.042 \\
(0.030)\end{array}$ \\
\hline 1992 Entry Cohort & - & - & - & - & $\begin{array}{c}0.008 \\
(0.012)\end{array}$ & $\begin{array}{c}0.017 \\
(0.018)\end{array}$ & $\begin{array}{c}0.025 \\
(0.029)\end{array}$ & $\begin{array}{c}0.035 \\
(0.034)\end{array}$ & $\begin{array}{c}0.038 \\
(0.034)\end{array}$ \\
\hline 1997 Entry Cohort & - & - & - & - & - & $\begin{array}{c}0.012 \\
(0.018)\end{array}$ & $\begin{array}{c}0.024 \\
(0.032)\end{array}$ & $\begin{array}{c}0.030 \\
(0.050)\end{array}$ & $\begin{array}{c}0.032 \\
(0.066)\end{array}$ \\
\hline 2002 Entry Cohort & - & - & - & - & - & - & $\begin{array}{c}0.009 \\
(0.017)\end{array}$ & $\begin{array}{c}0.016 \\
(0.028)\end{array}$ & $\begin{array}{c}0.021 \\
(0.029)\end{array}$ \\
\hline 2007 Entry Cohort & - & - & - & - & - & - & - & $\begin{array}{c}0.011 \\
(0.014)\end{array}$ & $\begin{array}{c}0.017 \\
(0.026)\end{array}$ \\
\hline 2012 Entry Cohort & - & - & - & - & - & - & - & - & $\begin{array}{c}0.006 \\
(0.008)\end{array}$ \\
\hline \multicolumn{10}{|l|}{$C B S A \mathrm{~s}$} \\
\hline 1972 Districts & $\begin{array}{c}0.039 \\
(0.103)\end{array}$ & $\begin{array}{c}0.125 \\
(0.212)\end{array}$ & $\begin{array}{c}0.172 \\
(0.246)\end{array}$ & $\begin{array}{c}0.212 \\
(0.259)\end{array}$ & $\begin{array}{c}0.250 \\
(0.310)\end{array}$ & $\begin{array}{c}0.276 \\
(0.333)\end{array}$ & $\begin{array}{c}0.298 \\
(0.368)\end{array}$ & $\begin{array}{c}0.306 \\
(0.379)\end{array}$ & $\begin{array}{c}0.317 \\
(0.391)\end{array}$ \\
\hline 1977 Entry Cohort & - & $\begin{array}{c}0.000 \\
(0.053)\end{array}$ & $\begin{array}{c}0.018 \\
(0.083)\end{array}$ & $\begin{array}{c}0.026 \\
(0.100)\end{array}$ & $\begin{array}{c}0.035 \\
(0.124)\end{array}$ & $\begin{array}{c}0.036 \\
(0.138)\end{array}$ & $\begin{array}{c}0.044 \\
(0.138)\end{array}$ & $\begin{array}{c}0.048 \\
(0.145)\end{array}$ & $\begin{array}{c}0.050 \\
(0.157)\end{array}$ \\
\hline 1982 Entry Cohort & - & - & $\begin{array}{c}0.000 \\
(0.035)\end{array}$ & $\begin{array}{c}0.019 \\
(0.063)\end{array}$ & $\begin{array}{c}0.033 \\
(0.083)\end{array}$ & $\begin{array}{c}0.039 \\
(0.100)\end{array}$ & $\begin{array}{c}0.047 \\
(0.115)\end{array}$ & $\begin{array}{c}0.051 \\
(0.127)\end{array}$ & $\begin{array}{c}0.055 \\
(0.136)\end{array}$ \\
\hline 1987 Entry Cohort & - & - & - & $\begin{array}{c}0.000 \\
(0.022)\end{array}$ & $\begin{array}{c}0.000 \\
(0.039)\end{array}$ & $\begin{array}{c}0.003 \\
(0.055)\end{array}$ & $\begin{array}{c}0.021 \\
(0.077)\end{array}$ & $\begin{array}{c}0.023 \\
(0.084)\end{array}$ & $\begin{array}{c}0.024 \\
(0.087)\end{array}$ \\
\hline 1992 Entry Cohort & - & - & - & - & $\begin{array}{c}0.000 \\
(0.039)\end{array}$ & $\begin{array}{c}0.015 \\
(0.059)\end{array}$ & $\begin{array}{c}0.029 \\
(0.084)\end{array}$ & $\begin{array}{c}0.037 \\
(0.100)\end{array}$ & $\begin{array}{c}0.040 \\
(0.110)\end{array}$ \\
\hline 1997 Entry Cohort & - & - & - & - & - & $\begin{array}{c}0.009 \\
(0.041)\end{array}$ & $\begin{array}{c}0.028 \\
(0.074)\end{array}$ & $\begin{array}{c}0.036 \\
(0.105)\end{array}$ & $\begin{array}{c}0.037 \\
(0.130)\end{array}$ \\
\hline 2002 Entry Cohort & - & - & - & - & - & - & $\begin{array}{c}0.000 \\
(0.030)\end{array}$ & $\begin{array}{c}0.000 \\
(0.050)\end{array}$ & $\begin{array}{c}0.005 \\
(0.059)\end{array}$ \\
\hline 2007 Entry Cohort & - & - & - & - & - & - & - & $\begin{array}{c}0.000 \\
(0.030)\end{array}$ & $\begin{array}{c}0.009 \\
(0.050)\end{array}$ \\
\hline 2012 Entry Cohort & - & - & - & - & - & - & - & - & $\begin{array}{c}0.000 \\
(0.010)\end{array}$ \\
\hline
\end{tabular}

Notes: Medians; interquartile range in parentheses. 
grow to sizes similar to mature districts? If the latter is true, how long does this process take? Do large numbers of special districts exit early in life as is common in private organizations?

Using data from the Census of Government between 1972 and 2017, a descriptive analysis is conducted to examine these questions. Overall, the evidence from table 1 and figure 1 suggests the rate of special district entry, while still positive, has been declining over time. This is somewhat contrary to the popular narrative that special districts are continuously increasing at a fast rate over time (Shi 2017). New entrants have limited market share and are small relative to existing special districts. Exit is nonzero, but relatively rare with the exit rate never being larger than 10 percent. Additionally, the exit rate is fairly consistent over time. Lastly, exiting districts tend to be small, both in terms of market share and relative size. The combination of these two forces, entry and exit, has led to a lower overall growth rate in more recent years (U.S. Census Bureau 2019).

When examining entry and exit by entry cohort, the second set of questions can be answered. In general, new entry cohorts are small by both in terms of market share and average size relative to existing districts. New entry cohorts do grow in size relative to surviving districts, but rarely reach the size of existing districts. This appears to be the result of low growth rates as exits do not appear to be the driver of small sizes. Lastly, it appears that special districts do not exhibit high levels infant mortality that is typical among private sector organizations (Caves 1998). Rather, special district exits accumulate over time suggesting special districts are created for a longerterm purpose and when that purpose no longer remains, districts are shuttered. That is, special districts are durable to a point. When the district's raison d'etre is gone, the district withers.

There are clear limitations to the analysis. By relying on the Census of Governments data for measuring special district entry and exit, a number of districts that fall outside of the Census $\mathrm{Bu}$ reau's strict definition of fiscal and administrative independence. These "dependent" districts can be an important source of entry and exit that are not captured by the Census data. ${ }^{9}$ This can lead to a biased view of the special district "market." Similarly, the ever-five-year nature of the Census of Governments limits our ability to track entry and exit on an annual basis. There is variation in between each Census that is collapsed by the nature of the data used. This variation may be useful in attempting to examine the factors associated with entry and exit, but is unavailable to scholars using these data. Even with these limitations, the Census of Governments is the only nationally representative and consistent dataset for these kinds of analyses.

From the state perspective, special districts are typically an under-monitored part of the local government ecosystem. ${ }^{10}$ Sometimes referred to as "shadow governments," special districts are out of the limelight for many taxpayers and state legislators (Eger 2004). Therefore, providing a data-driven descriptive analysis of trends in the special district "marketplace" is of some import. Overall, this analysis begins a conversation about more robustly tracking special districts over time and space to get a better idea of how the entire system is changing. Relative general purpose governments, special districts enter and exit the local government ecosystem often. We have little to no concrete evidence of how this might change service delivery, though we can make inferences from the descriptive analysis presented here. If entry and exit is being determined by demand for services, there may be little cause for concern; however, if these factors are being driven by policy changes or other exogenous factors, there may be a role for state governments to take a more

\footnotetext{
${ }^{9}$ See Leigland (1990b) for a comparison between Census of Governments and Moody's Municipal and Government Manual enumerations of special districts.

${ }^{10}$ See California's Special Districts Annual Report (https://bythenumbers.sco.ca.gov/) and Florida's Special District Accountability Program (http://www.floridajobs.org/community-planning-and-development/specialdistricts/special-district-accountability-program) as important standouts.
} 
active role. There is inconsistent evidence for the former (Carr and Farmer 2011; Billings and Carroll 2012; Goodman 2018), and little evidence for the latter (Bauroth 2010).

While there is a nascent literature on the factors associated with the usage and/or creation of special districts (and a more limited one on dissolution), there has been little innovation in the measurement of these phenomena. The literature is currently dominated by count variables as a means to measure entry or exit. This descriptive analysis presents a method for moving the literature forward by presenting a host of alternate variables to examine such concepts. In addition to a potential measurement improvement, this analysis demonstrates that special district entry and exit is far more nuanced than previously assumed. By moving beyond simple counts to more complex measures of entry and exit, more complex questions can be asked.

\section{References}

Bauroth, Nicholas. 2010. "The Strange Case of the Disappearing Special Districts: Toward a Theory of Dissolution." The American Review of Public Administration 40 (5): 568-592.

— . 2015. "Hide In Plain Sight: The Uneven Proliferation of Special Districts Across the United States by Size and Function." Public Administration Quarterly 39 (2): 295-324.

Berry, Christopher R. 2009. Imperfect Union: Representation and Taxation in Multilevel Governments. Cambridge: Cambridge University Press.

Billings, Stephen B., and Deborah A. Carroll. 2012. "Debrucing the Link Between Tax and Expenditure Limits and Special District Governments." Growth and Change 43 (2): 273-303.

Bollens, John C. 1957. Special District Governments in the United States. Berkeley and Los Angeles: University of California Press.

Bowler, Shaun, and Todd Donovan. 2004. "Evolution in state governance structures: Unintended consequences of state tax and expenditure limitations." Political Research Quarterly 57 (2): 189196.

Briffault, Richard. 1993. "Who Rules at Home? One Person/One Vote and Local Governments." University of Chicago Law Review 60 (2): 339-424.

Burns, Nancy. 1994. The Formation of American Local Governments: Private Values in Public Institutions. New York, NY: Oxford University Press.

California Senate Local Government Committee. 2010. What's So Special About Special Districts? A Citizen's Guide to Special Districts in California. Sacramento, CA: California Senate Local Government Committee.

Carr, Jered B. 2006. "Local Government Autonomy and State Reliance on Special District Governments: A Reassessment." Political Research Quarterly 59 (3): 481-492.

Carr, Jered B., and Jayce Farmer. 2011. "Contingent Effects of Municipal and County TELs on Special District Usage in the United States." Publius: The Journal of Federalism 41 (4): 709-733.

Caves, Richard E. 1998. "Industrial Organizations and New Findings on Turnover and Mobility of Firms." Journal of Economic Literature 36 (4): 1947-1982.

Dunne, Timothy, Mark J. Roberts, and Larry Samuelson. 1988. "Patterns of Firm Entry and Exit in U.S. Manufacturing Industries." RAND Journal of Economics 19 (4): 495-515. 
Eger, Robert J., III. 2004. "Casting Light on Shadow Government: A Typology Approach.” Journal of Public Administration Research and Theory 16 (1): 125-137.

Foster, Kathryn A. 1997. The Political Economy of Special-Purpose Government. Washington D.C.: Georgetown University Press.

Goodman, Christopher B. 2018. "Usage of Specialized Service Delivery: Evidence from Contiguous Counties." Publius: The Journal of Federalism 48 (4): 686-708.

Goodman, Christopher B., and Suzanne M. Leland. 2019. “Do Cities and Counties Attempt to Circumvent Changes in Their Autonomy by Creating Special Districts?" The American Review of Public Administration 49 (2): 203-217.

Guild, Frederic H. 1918. “Special Municipal Corporations.” American Political Science Review 12 (4): 678-684.

— . 1920. "Special Municipal Corporations." American Political Science Review 14 (2): 286-291.

Hager, Mark A., Joseph Galaskiewicz, and Jeff A. Larson. 2004. "Structural embeddedness and the liability of newness among nonprofit organizations." Public Management Review 6 (2): 159-199.

Hannan, Michael T., and John Freeman. 1977. "The Population Ecology of Organizations." American Journal of Sociology 82 (5): 929-964.

Kettleborough, Charles. 1914. "Special Municipal Corporations." American Political Science Review 8 (4): 614-621.

— . 1915. "Special Municipal Corporations." American Political Science Review 9 (4): 751-759.

Leigland, James. 1990a. "In Defense of a Preoccupation with Numbers: A Response." Western Political Quarterly 43 (2): 385-386.

— . 1990b. "The Census Bureau's Role in Research on Special Districts: A Critique." Western Political Quarterly 43 (2): 367-380.

— . 1992. "External Controls on Public Authorities and Other Special Purpose Governments." In Public Authorities and Public Policy: The Business of Government, ed. by Jerry Mitchell. New York: Greenwood Press.

— . 1994. "Public Authorities and the Determinants of Their Use by State and Local Government." Journal of Public Administration Research and Theory 4 (4): 521-544.

Lewis, Paul G. 2000. "The Durability of Local Government Structure: Evidence from California." State E Local Government Review 32 (1): 34-48.

MacManus, Susan A. 1981. "Special District Governments: A Note on Their Use As Property Tax Relief Mechanisms in the 1970s." The Journal of Politics 43 (4): 1207-1214.

McCabe, Barbara C. 2000. "Special-District formation among the states." State E Local Government Review 32 (2): 121-131.

Mehay, Stephen L. 1984. "The effect of governmental structure on special district expenditures." Public Choice 44 (2): 339-348.

Moldogaziev, Tima T., Tyler A. Scott, and Robert A. Greer. 2019. “Organizational Dissolutions in the Public Sector: An Empirical Analysis of Municipal Utility Water Districts." Journal of Public Administration Research and Theory 29 (4): 535-555. 
Nelson, Michael A. 1990. "Decentralization of the Subnational Public Sector: An Empirical Analysis of the Determinants of Local Government Structure in Metropolitan Areas in the US." Southern Economic Journal 57 (2): 443-457.

Oakerson, Ronald J., and Roger B. Parks. 1989. “Local Government Constitutions: A Different View of Metropolitan Governance." The American Review of Public Administration 19 (4): 279294.

Perrenod, Virginia Marion. 1984. Special Districts, Special Purposes: Fringe Governments and Urban Problems in the Houston Area. College Station, TX: Texas A\&M University Press.

Porter, Kirk H. 1933. “A Plague of Special Districts.” National Municipal Review 22 (11): 544-574.

Sacks, Seymour. 1990. "“The Census Bureau's Role in Research on Special Districts: A Critique”: A Necessary Rejoinder." Western Political Quarterly 43 (2): 381-383.

Shi, Yu. 2017. "The Rise of Specialized Governance in American Federalism: Testing Links Between Local Government Autonomy and Formation of Special District Governments." Publius: The Journal of Federalism 47 (1): 99-130.

Stigler, George J. 1971. "The Theory of Economic Regulation." The Bell Journal of Economics and Management 2:3-21.

Stinchcombe, Arthur L. 1965. "Social Structure and Organizations." In Handbook of Organizations, ed. by James G March, 153-193. Chicago: Rand McNally.

Tiebout, Charles M. 1956. "A Pure Theory of Local Expenditures." Journal of Political Economy 64 (5): 416-424.

U.S. Census Bureau. 2006. Government Finance and Employment Classification Manual. Washington D.C.: Government Printing Office.

— . 2019. 2017 Census of Governments, Individual State Descriptions. Washington D.C.: Government Printing Office.

Wholey, Douglas R., Jon B. Christianson, and Susan M. Sanchez. 1992. “Organization Size and Failure Among Health Maintenance Organizations." American Sociological Review 57 (6): 829842. 